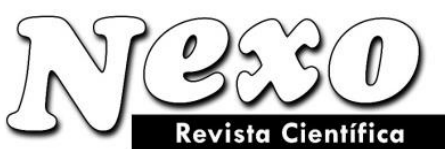

Vol. 33, No. 02, pp. 321-339/Diciembre 2020
ISSN-E 1995-9516

Universidad Nacional de Ingeniería COPYRIGHT @ (UNI). TODOS LOS DERECHOS RESERVADOS http://revistas.uni.edu.ni/index.php/Nexo https://doi.org/10.5377/nexo.v33i02.10772

\title{
Petrography and geochemistry of intrusive magmas in Varmaqan - Sardare ghobadi in the west of Iran
}

\section{Petrografía y geoquímica de magmas intrusivos en Varmaqan - Sardare ghobadi en el oeste de Irán}

\author{
Negin Davari, Mohammad Ali Arian*, Afshin Ashja Ardalan, Mohammad Reza Jafari \\ Department of Geology, North Tehran Branch, Islamic Azad University, Tehran, Iran. \\ *Corresponding author Email: m-arian@iau-tnb.ac.ir
}

(recibido/received: 02-May-2020; aceptado/accepted: 15-July-2020)

\begin{abstract}
The study area is a quadrilateral of $155 \mathrm{~km}^{2}$ between eastern longitude $47^{\circ}$ and $40^{\prime}$ to $47^{\circ}$ and $52^{\prime}$ and northern latitudes $35^{\circ}$ and $00^{\prime}$ to $35^{\circ}$ and $04^{\prime}$ that is located in west of Iran, north of Sonqor city and between Varmaqan and Sardare Ghobadi villages of Kermanshah province. In this range, the intrusive rocks are alkaline granite, granite, granodiorite, tonalite, quartz alkaline syenite, quartz monzonite, quartz monzodiorite, quartz diorite, alkaline syenite, monzonite, diorite, gabbro diorite, gabbro, and olivine gabbro as they were injected in the iron ores of cretaceous which has resulted in contact metamorphism and created hornfels at the site of contact. After comprehensive sampling of all required igneous rocks and according to the thesis objectives, thin sections were prepared and after petrography and some samples were selected for geochemical experiments. XRF analysis, ICP and alkaline fusion were performed on some samples. According to geochemical and petrological studies, the magmas forming these intrusive igneous rocks are from one region and because of magmatic differentiation or fractional crystallization, they from basaltic to acidic terms. Samples of this quadrilateral have a metaalumina nature and granitoids are in the range of arc islands granites, continental arc granitoids and continental collision granitoids. The mineralogical and chemical composition of the acidic rocks in the area show that the granites in this study are type I.
\end{abstract}

Keywords: Petrography, Geochemistry, Intrusive, Sardare Ghobadi, Iran

\section{RESUMEN}

El área de estudio es un cuadrilátero de $155 \mathrm{~km}^{2}$ entre la longitud oriental $47^{\circ}$ y 40 'a $47^{\circ}$ y $52^{\prime}$ y las latitudes norte $35^{\circ}$ y 00 'a $35^{\circ}$ y $04^{\prime}$ que se encuentra al oeste de Irán, al norte de la ciudad de Sonqor y entre las aldeas Varmaqan y Sardare Ghobadi de la provincia de 
Kermanshah. En este rango, las rocas intrusivas son granito alcalino, granito, granodiorita, tonalita, sienita alcalina de cuarzo, monzonita de cuarzo, monzodiorita de cuarzo, diorita de cuarzo, sienita alcalina, monzonita, diorita, diorita de gabro, gabro y gabro de olivina cuando se inyectaron. los minerales de hierro del cretáceo que han resultado en metamorfismo de contacto y creado hornfels en el sitio de contacto. Después del muestreo exhaustivo de todas las rocas ígneas requeridas y de acuerdo con los objetivos de la tesis, se prepararon secciones delgadas y después de la petrografía y se seleccionaron algunas muestras para experimentos geoquímicos. Análisis de XRF, ICP y fusión alcalina se realizaron en algunas muestras. De acuerdo con estudios geoquímicos y petrológicos, los magmas que forman estas rocas ígneas intrusivas son de región y, debido a la diferenciación magmática o cristalización fraccionada, pasan de términos basálticos a ácidos. Las muestras de este cuadrilátero tienen una naturaleza de meta-alúmina y los granitoides están en el rango de granitos de islas de arco, granitoides de arco continental y granitoides de colisión continentales. La composición mineralógica y química de las rocas ácidas en el área muestra que los granitos en este estudio son de tipo I.

Palabras clave: Petrografía, Geoquímica, Intrusiva, Sardare Ghobadi, Irán

\section{INTRODUCCIÓN}

Kermanshah province in located in the west of Iran, with an area of 24640 square kilometers and located between eastern longitude $45^{\circ}$ and $20^{\circ}$ and $39^{\prime \prime}$ to $48^{\circ}$ and $01^{\prime}$ and $58^{\prime \prime}$ and northern latitude $33^{\circ}$ and $37^{\prime}$ and $08^{\prime \prime}$ to $35^{\circ}$ and $17^{\prime}$ and $08^{\prime \prime}$. Kermanshah province is a mountainous area that lies between the Iranian plateau and the Mesopotamian Plateau and is covered by the Zagros Mountain Peak and Highlands. The studied intrusions were injected into the Sanandaj-Sirjan metamorphic belt. Their injections are from the Cretaceous to the late Eocene and early Oligocene (Tarabi et al. 2019, Yazdi et al. 2019, Jamshidibadr et al. 2020). The basaltic magmas in this region have mantle origin and the more silicic magmas come from the fractionation of them and crustal contamination (Ashrafi et al. 2018, Mobashergermi et al. 2018, Nazemi et al. 2019, Baratian et al. 2020).

The study area is amongst the formations of the young Zagros mountain range that extends from northwest to southeast of Iran. Due to its geological conditions, this quadrilateral is in a fragmented area and in terms of Iran's geological divisions, it is located in the Sanandaj - Sirjan zone which its oldest formation is the Jurassic and the youngest is the young Quaternary alluvium.

\section{RESEARCH PURPOSES}

1- Field operations including sampling taking oriented geological samples of geological phenomena and the preparation of thin sections.

2- Study of geochemical changes of elements and some of their compounds based on international standard charts.

3- Study of geochemical changes of elements and some of their compounds based on international standard charts.

4- Summarizing all quantitative, qualitative and laboratory data .

5- Determination of intrusive magma origin. 


\section{GEOLOGY OF THE STUDY AREA}

The complex of intrusive rocks in this study area belong to Eocene - Oligocene. The diorite unit in this complex is in the form of eastern-western dikes with a northern slope in which granite veins have intruded.

The rocks age relationship in this complex is not known, but given the influence of granite veins within diorite, it is clear that granite is younger than the more mafic rocks and is probably the result of a separate period of magmatism. Like the Sanandaj - Sirjan zone, this area has active tectonics and several faults and joints have been created in its general northwest-southeast trend corresponding to the zones trend. The operation of this fault has caused many joints and cracks in the region's rocks, including the diorite unit in which granite veins have been injected. This indicates that the veins were injected after the fault.

Intrusive masses are the most important and prominent manifestation of magmatism in this region, and the existing morphology is mainly influenced by them.
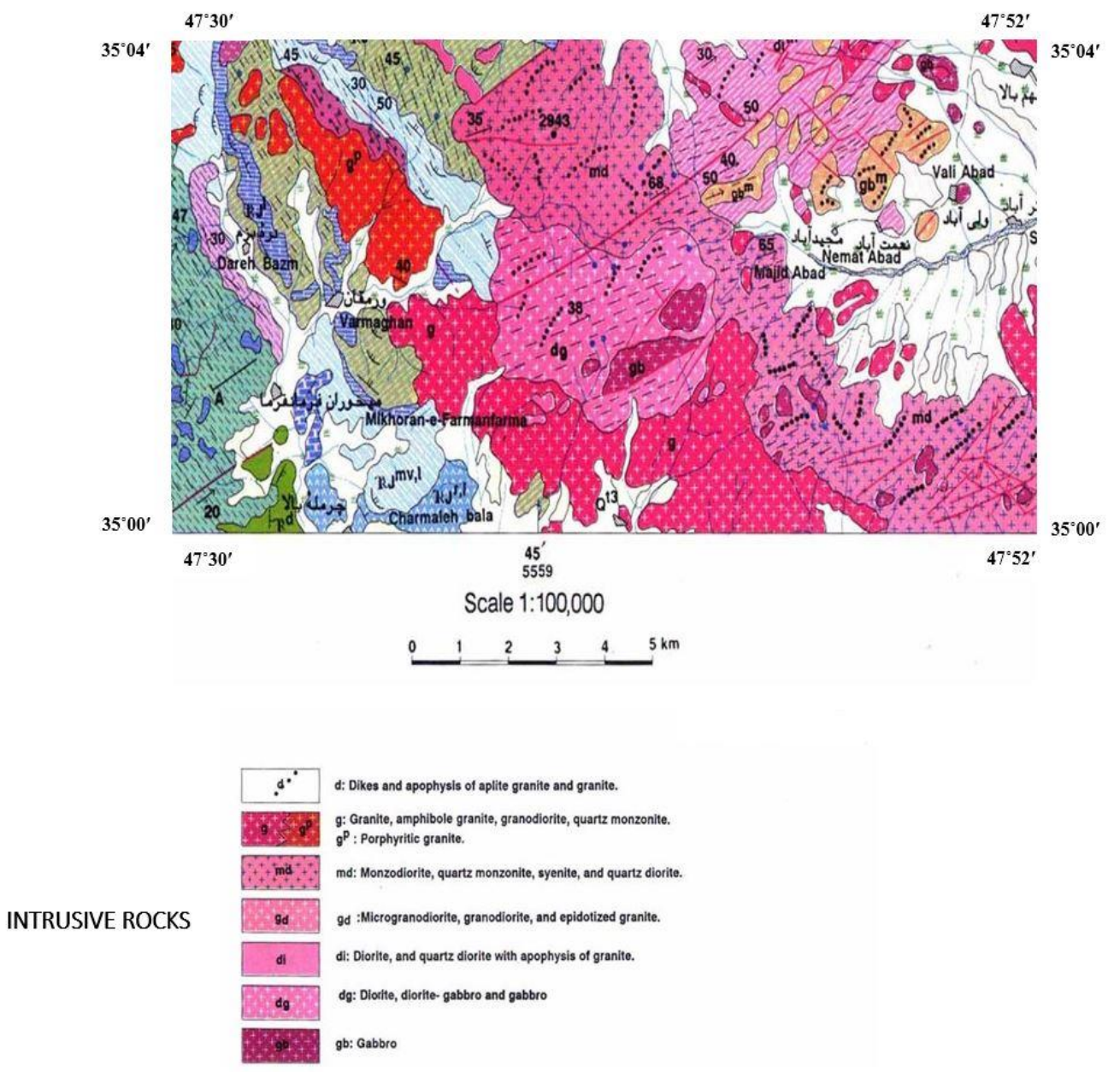

Figure 1. Geological map of 1: 100000 Qorveh. (Ministry of mines and metals and Geological survey of Iran, 1999) 


\section{PETROGRAPHY}

Petrographic study of the rocks within the range of study indicates different ranges of igneous rocks. The rocks in this quadrilateral are classified according to the Streckeisen classification (1974 - 1980) as: alkaline granite, granite, granodiorite, tonalite, quartz alkaline syenite, quartz monzonite, quartz monzodiorite, quartz diorite, alkaline syenite, monzonite, diorite, gabbro diorite, gabbro, and olivine gabbro.

In Fig. 2, the rocks of the study area are plotted on the QAP triangle.

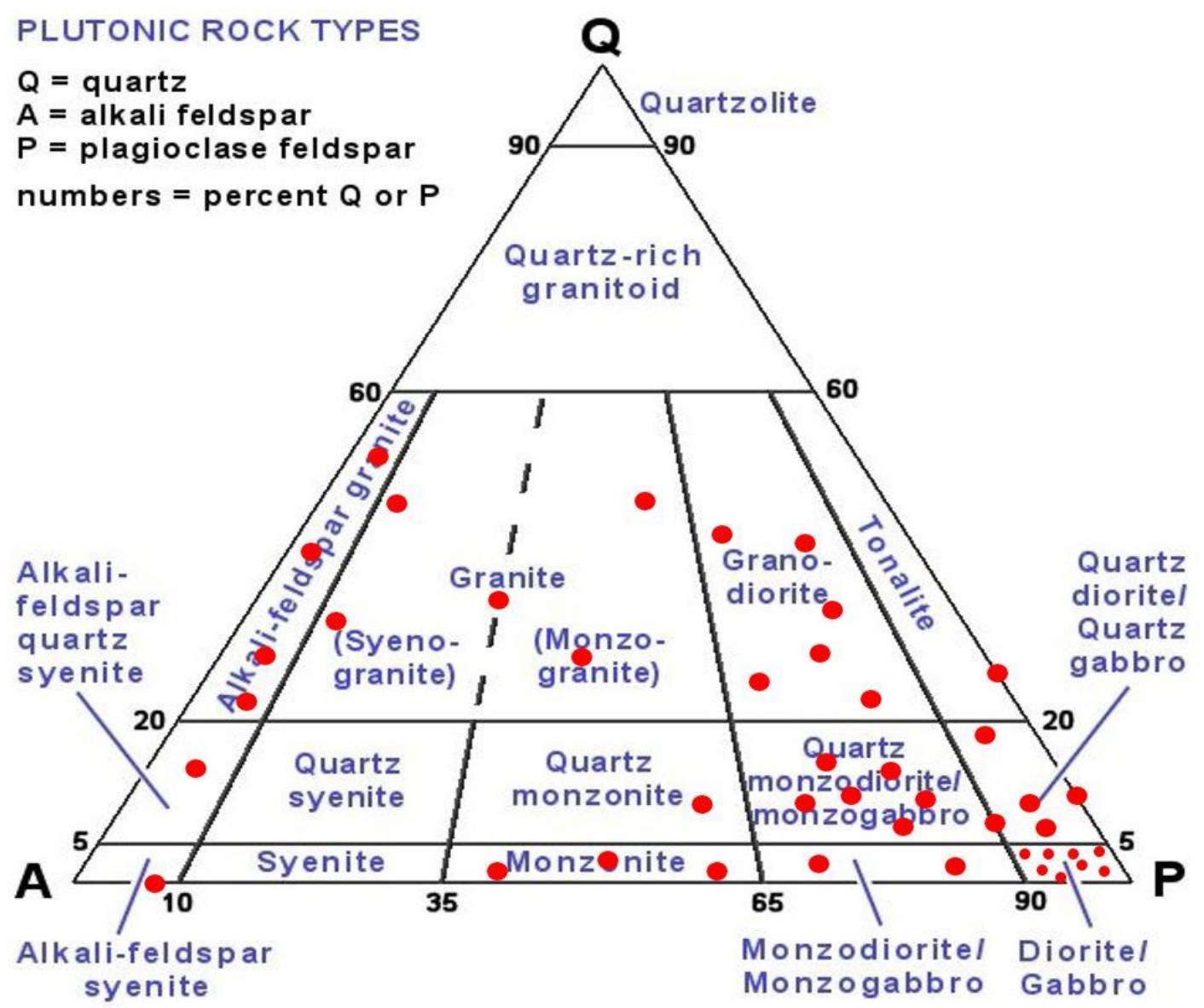

Figure 2. Studied rocks plotted on the Streckeisen 1974 diagram

Granite: The texture of these granites varies between coarse-grained, graphic and myrmecitic. The principal constituents of the granites are quartz, orthos, microcline, plagioclase and biotite. Quartz is amorphous and in small to large sizes, they are fillers between minerals. Orthos present in the samples are cloudy and semi-automorphic. In one sample, peritonitis orthosis has been seen (due to the simultaneous growth of potassic and sodic alkali feldspars at low temperatures and in two separate phases but in each other).

* All the figures have been scaled by millimeters. 


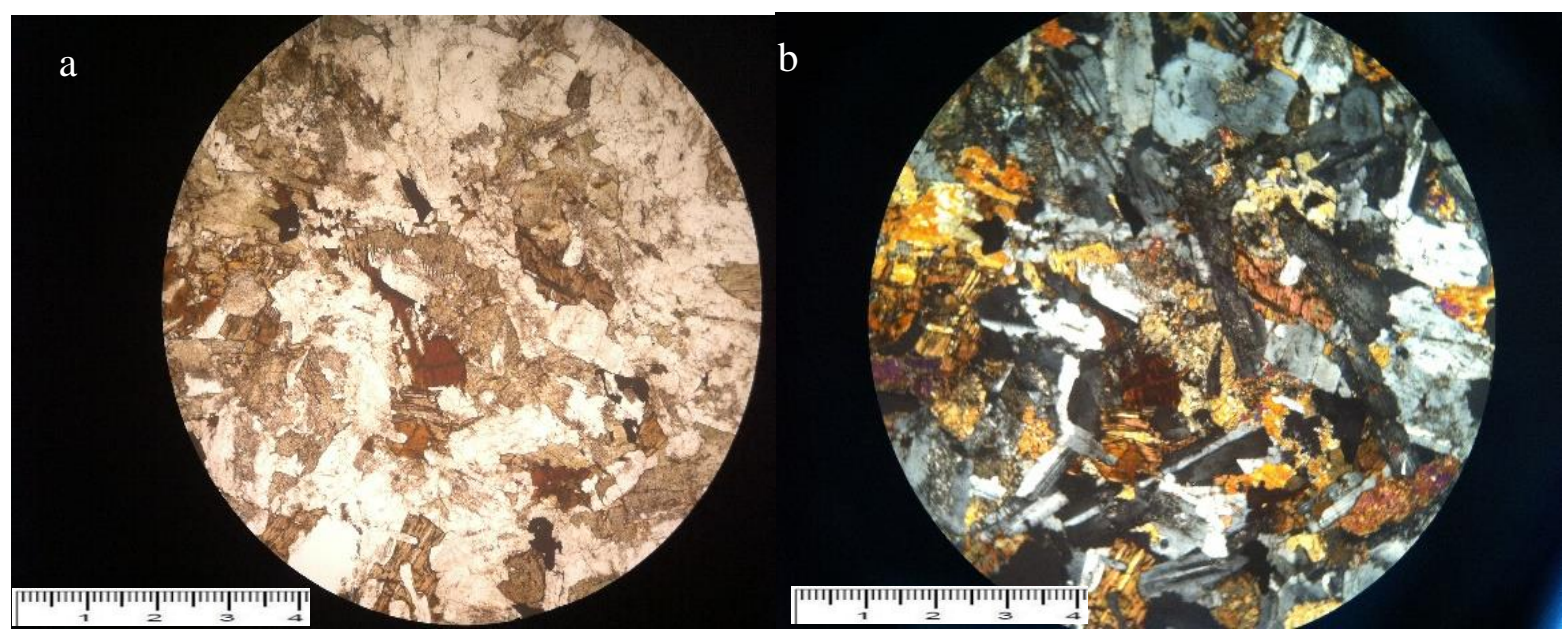

Figure 3. 40x granite microscopic image in a) ppl vision, where biotite and hornblend crystals are visible, and b) xpl vision, which is characterized by orthoses and plagioplase.

Granodiorite: The granular texture consists of quartz, oligoclase and sometimes andesine plagioclase, orthoclase and microcline alkali feldspars, muscovite, and iron and magnesium minerals such as biotite and hornblende.

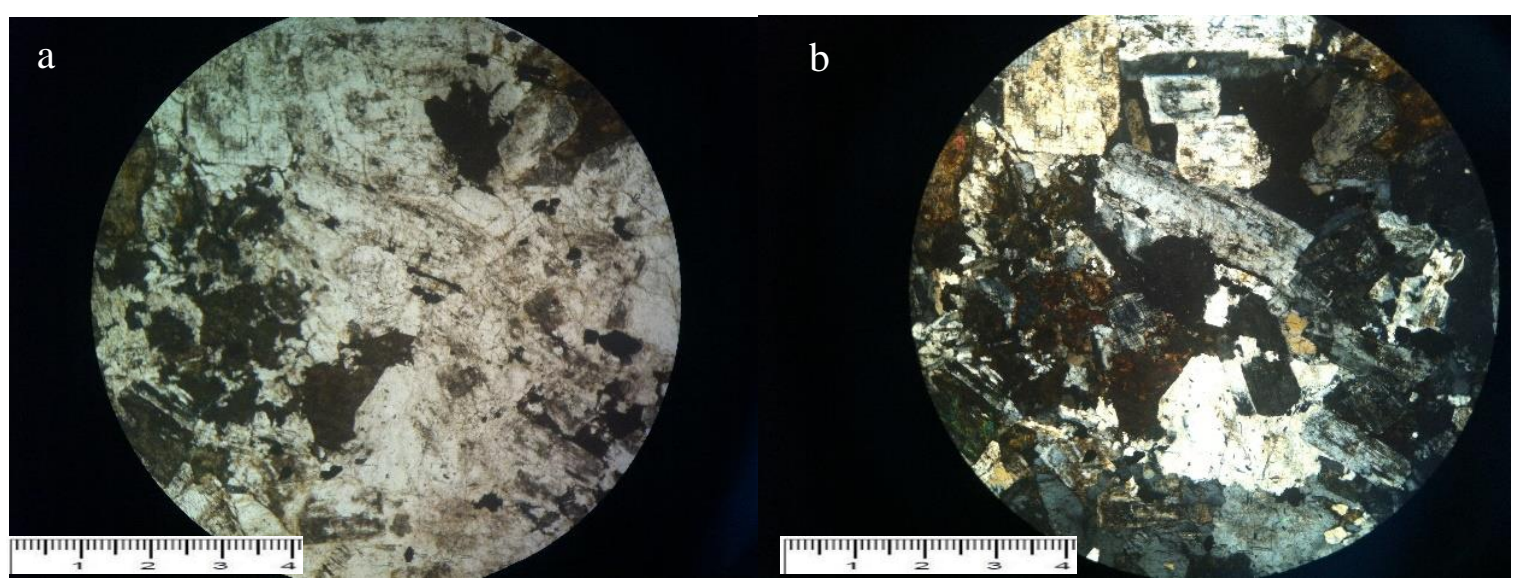

Figure 4. 40x granodiorite microscopic image in a) ppl vision, where biotite and hornblend crystals are visible, and b) xpl vision, which is characterized by orthoses and plagioplase.

Quartz Monzodiorite: The texture is medium to fine-grained in various samples. principal constituents are plagioclase, hornblende and augite. 


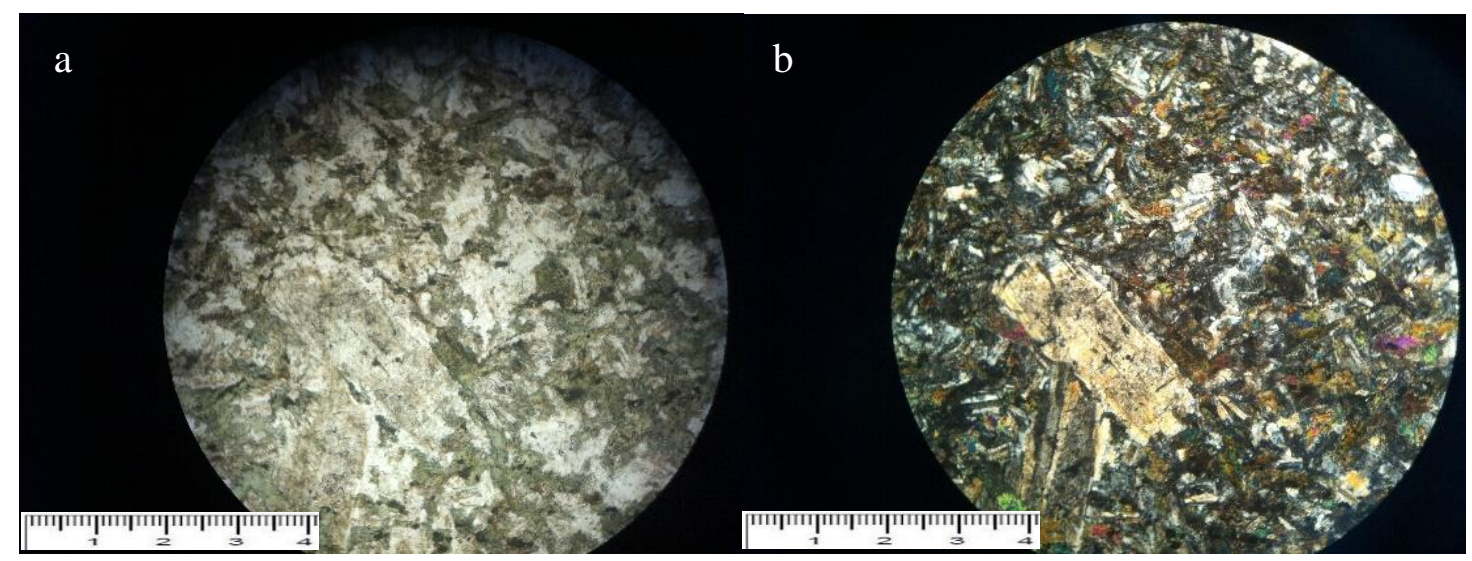

Figure 5. 40x quartz monzodiorite microscopic image in a) ppl vision, where a large number of hornblend crystals are visible, and b) xpl vision, which a large numbre of plagioclase and one big plagioclase in the middle of the field of view are visible.

Quartz diorite: The principal constituents of quartz diorite are plagioclase and hornblende. The great amount of plagioclases in all specimens are all automorphic with parallel twining, and high alteration. Minor minerals of quartz diorites are quartz, microcline, augite and biotite. Quartz minerals are present in all samples among other crystals in very small amounts and in small sizes.

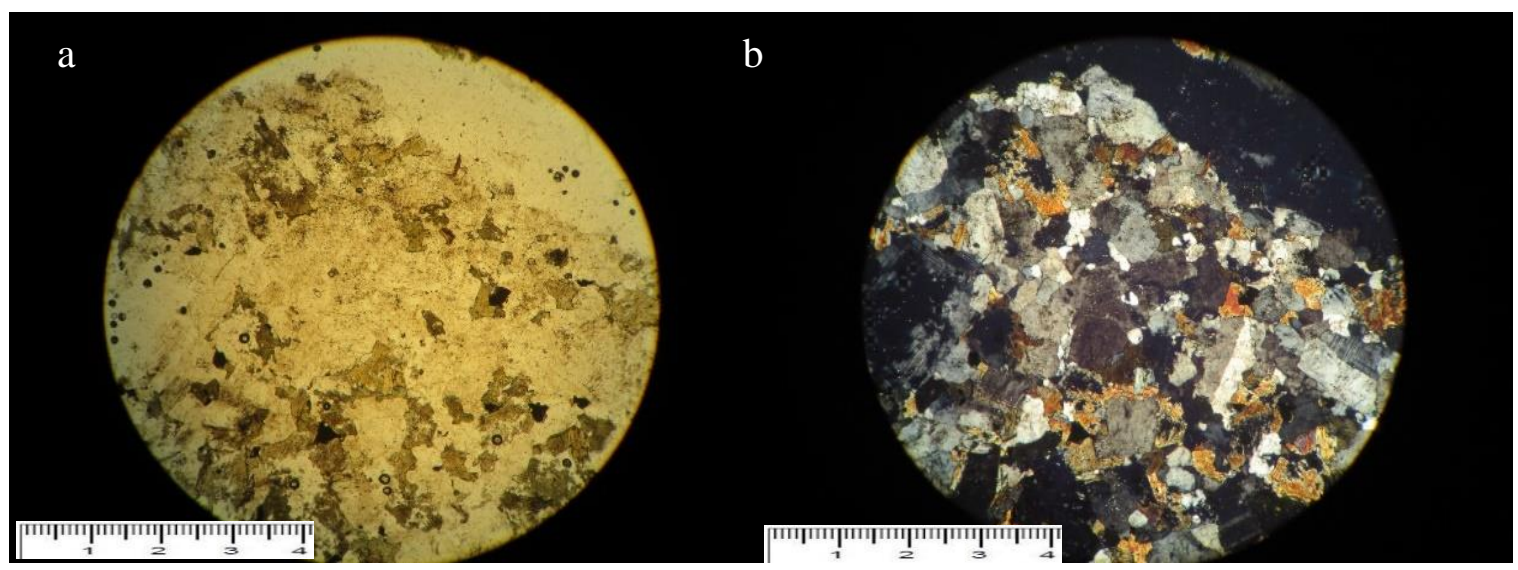

Figure 6. 40x quartz diorite microscopic image in a) ppl vision, and b) xpl vision .

Alkaline Syenite: The principal constituent of this rock is sodium rich and highly perthite microcline. Another important characteristic of syenites is their high sodium and potassium levels. Orthoclase, microcline, oligoclase and albite are the most important feldspars that form these alkaline synenites. There is no quartz in these samples. 


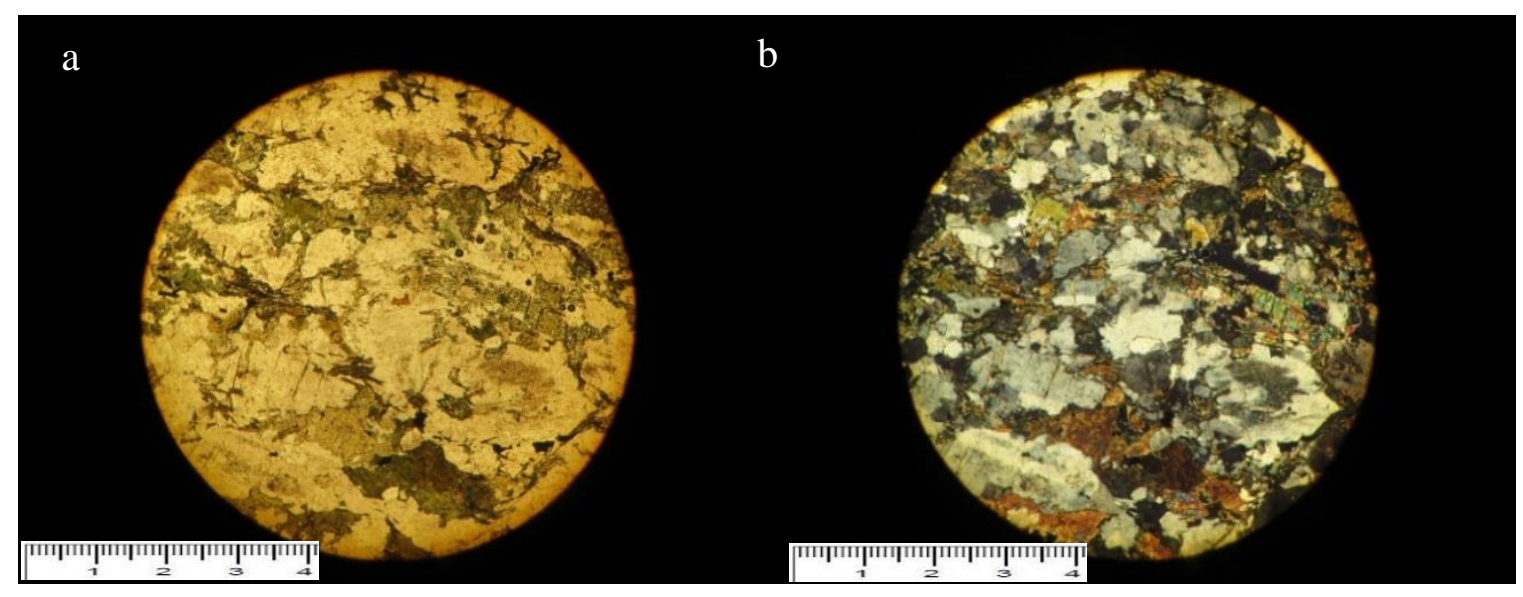

Figure 7. 40x alkaline syenite microscopic image in a) ppl vision, where a number of hornblend, alkaline crystals of albite and apatite type, and opaq crystals are visible, and b) xpl vision .

Monzonite: In monzonites the percentage of alkaline feldspar is equal to plagioclase. The fine-grained, medium-grained, cumulus, and porphyry granular textures are visible in different specimens. In porphyry monzonites, plagioclase crystals are coarse. The principal constituents are oligoclase and andesine plagioclase, orthoclase and hornblende and its minor minerals are biotite and opaque.

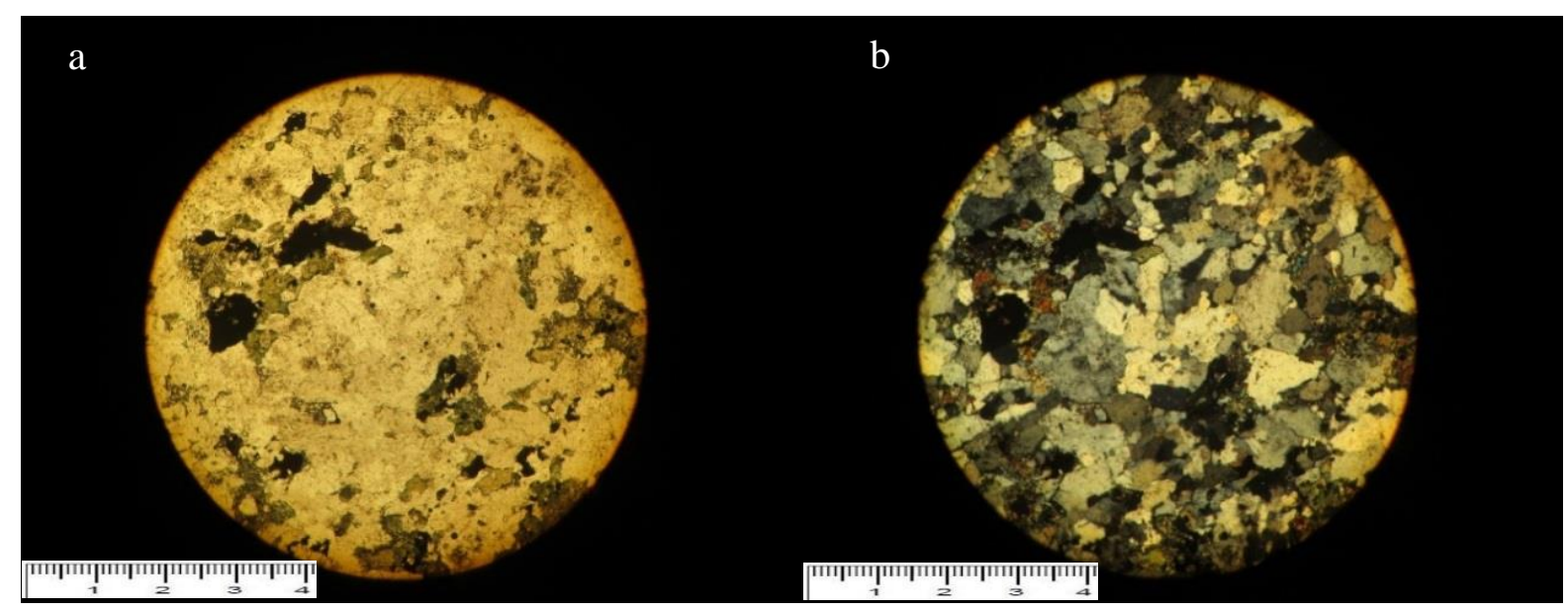

Figure 8. 40x monzonite microscopic image in a) ppl vision, where a number of plagioclase, ortoclase, green hornblend, and opaq crystals are visible, and b) xpl vision .

Diorite: Medium-grain texture. The principal constituents of these diorites are plagioclase, hornblende and augite and its minor minerals are orthos, quartz, opaque and biotite. 


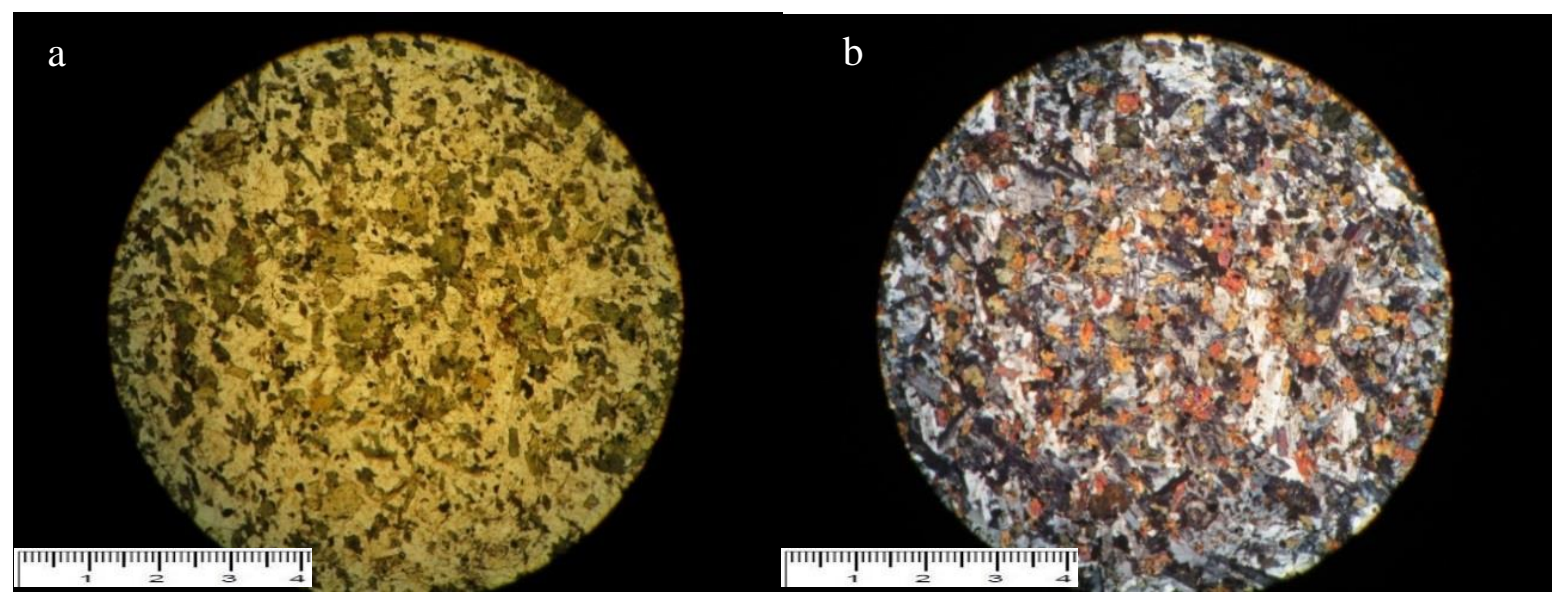

Figure 9. 40x micro diorite microscopic image in a) ppl vision, where a number of plagioclase, green hornblend, and opaq crystals are visible, and b) xpl vision .

Diorite gabbro: The composition of this rock varies between diorite and gabbro, in which the plagioclases have about 50\% anorthite. Textures are granular and of medium type, coarse grained and pegmatoidic. The principal constituents of diorite gabbros are plagioclase, augite, hornblende and opaque crystals.

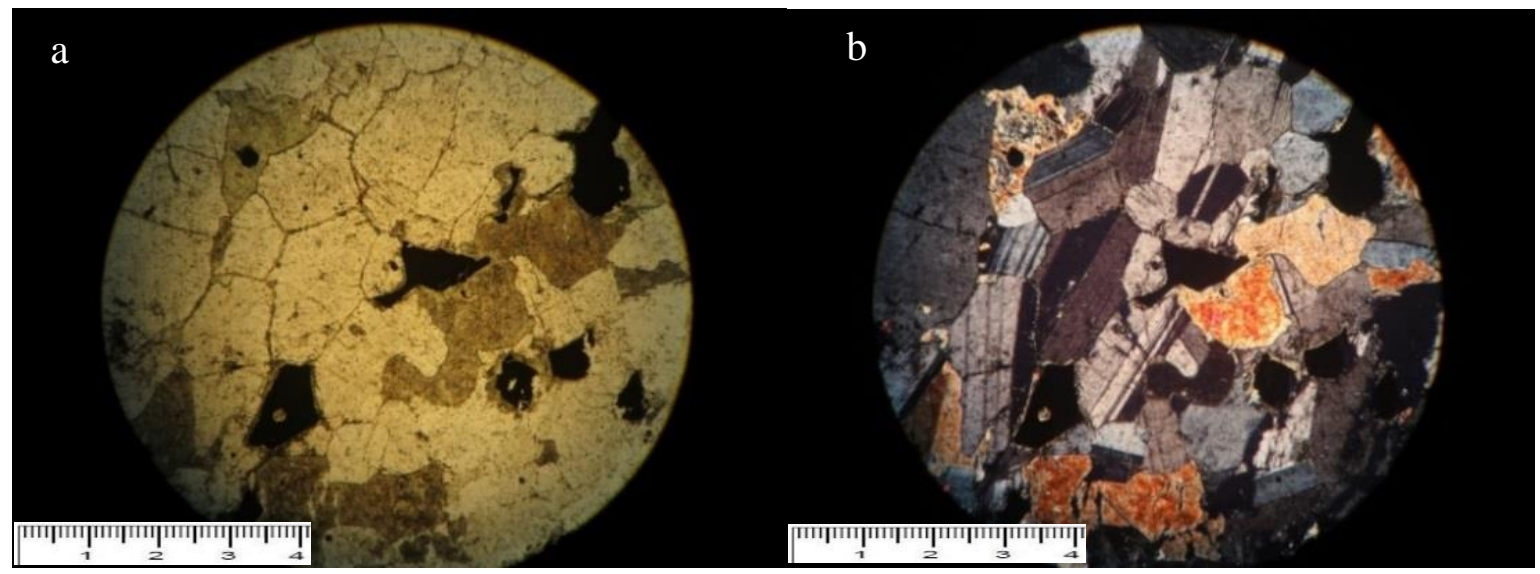

Figure 10. 40x diorite gabbro microscopic image in a) ppl vision, where high birefrenjanse greenish cream augites alonge with plagioclase are visible, and b) xpl vision .

Olivine Gabbro: The texture of these rocks is granular from medium-grain to coarse-grained. In some samples the texture is pegmatoidic. The plagioclases of these olivine gabbros have anorthite values of An 50 to An 66. Clinopyroxen types are augite and $\mathrm{Mg} /\left(\mathrm{Mg}+\mathrm{Fe}^{\text {total }}\right)$ varies from 0.60 to 0.84 . Biotite is found in small quantities and shows a second level red interference color. The olivines in these rocks are colorless, shapeless and lacking in cleavage, showing late interactive second series colors. A considerable amount of irregular cracks is seen in thin sections. 


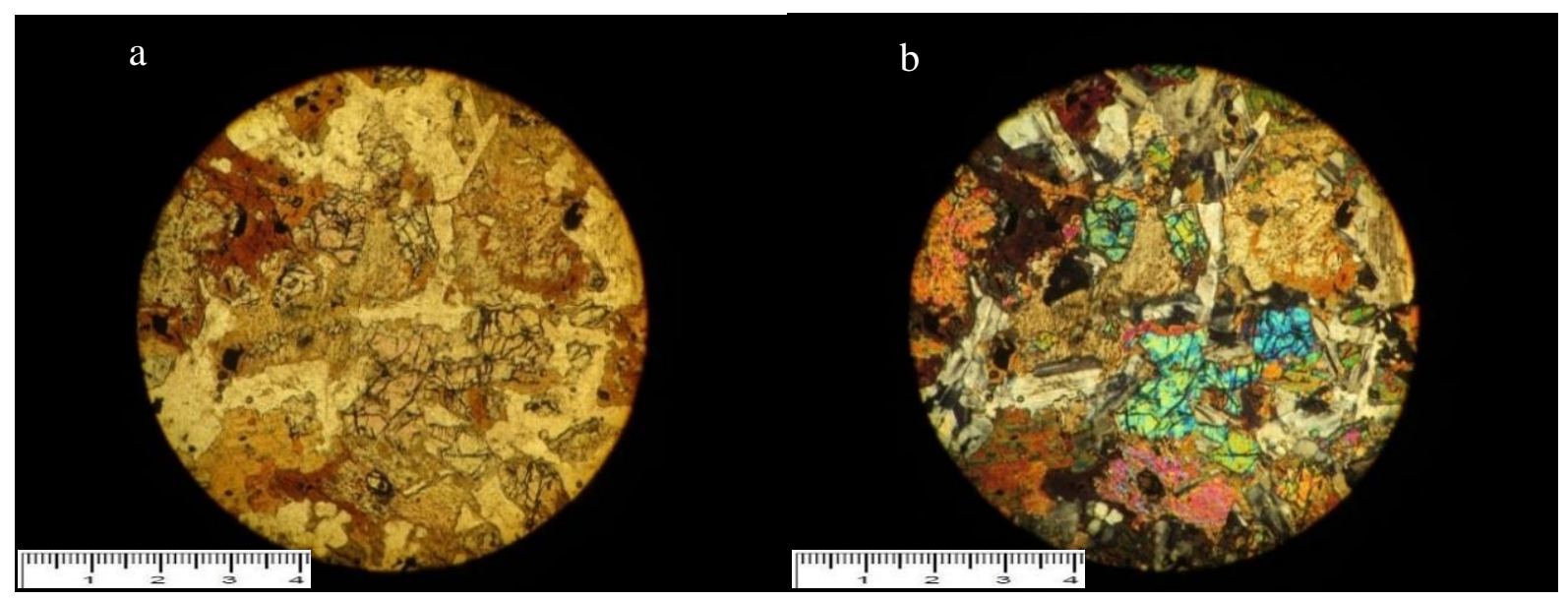

Figure 11. 40x olivine gabbro microscopic image in a) ppl vision , and b) xpl vision .

\section{DETECTION OF GRANITE TYPES IN THE STUDIED AREA}

In table 1 the granites of type $\mathrm{S}$ and I are compared with each other.

Table 1. Comparison of S and I granites (Chapel \& White, 1974)

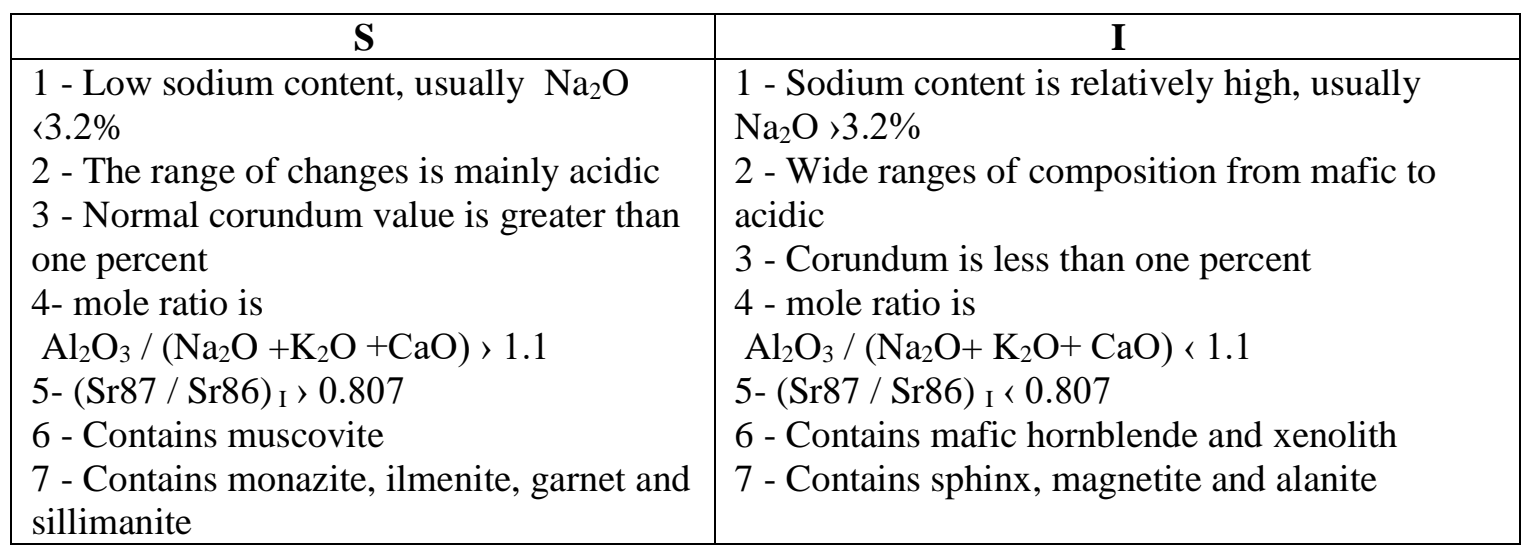

Considering the above figure and given that the samples in the study range, based on the results of the chemical analysis of the major oxides, contain $\mathrm{Na}_{2} \mathrm{O}>3.2 \%$, as well as the range of variations from acidic to alkaline, and that by calculating the minerals of the rocks under study, the corundum content is less than $1 \%$, and also by molar ratio that is $\mathrm{Al}_{2} \mathrm{O}_{3} /\left(\mathrm{Na}_{2} \mathrm{O}+\mathrm{K}_{2} \mathrm{O}+\right.$ $\mathrm{CaO})<1.1$, and according to the results of microscopic studies, the samples under study have high levels of hornblende, contain levels of magnetite and alanite and lack muscovite, monazite, garnet and silimanite, hence it can be concluded the studied granites are I type.

\section{GEOCHEMISTRY}

For chemical rock naming, determination of magma crystallization conditions and melting processes, 24 samples were chemically analyzed and results obtained from sample analysis using 
related software such as Ig Pet, GCD Kit, Min Pet, Petrographic and etc. was processed, debated and reviewed.

The results of chemical analysis are shown in the following tables and diagrams:

Table 2. Correction for Loss On Ignition (L.O.I)

\begin{tabular}{|c|c|c|c|c|c|c|c|c|c|c|c|c|c|c|}
\hline sample & $\mathrm{SiO}_{2}$ & $\mathbf{A l}_{2} \mathbf{O}_{3}$ & $\mathbf{B a O}$ & $\mathrm{CaO}$ & FeTotal & $\mathrm{FeO}$ & $\mathrm{Na}_{2} \mathrm{O}$ & $\mathrm{Fe}_{2} \mathrm{O}_{3}$ & $\mathbf{K}_{2} \mathbf{O}$ & $\begin{array}{r}\mathrm{Na}_{2} \mathrm{O}+ \\
\mathbf{K}_{2} \mathrm{O} \\
\end{array}$ & MgO & MnO & $\mathbf{P}_{2} \mathbf{O}_{5}$ & $\mathrm{TiO}_{2}$ \\
\hline D102 & 51.73 & 15.31 & 0.052 & 14.157 & 8.887 & 5.50994 & 2.52 & 3.37706 & 0.6 & 3.12 & 7.694 & 0.198 & 0.177 & 1.179 \\
\hline D103 & 52.266 & 20.17 & 0.052 & 10.97 & 9.78 & 5.6724 & 4.15 & 4.1076 & 0.337 & 4.487 & 3.95 & 0.147 & 0.147 & 2.266 \\
\hline D104 & 63.279 & 16.36 & 0.052 & 7.15 & 5.69 & 2.7881 & 5.515 & 2.9019 & 2.688 & 8.203 & 3.22 & 0.085 & 0.232 & 1.222 \\
\hline D105 & 64.608 & 15.97 & 0.052 & 6.036 & 6.143 & 2.94864 & 5.345 & 3.19436 & 2.869 & 8.214 & 2.62 & 0.053 & 0.2869 & 1.349 \\
\hline D109 & 50.18 & 12.77 & 0.052 & 15.65 & 10.287 & 6.37794 & 2.136 & 3.90906 & 0.248 & 2.384 & 9.094 & 0.207 & 0.134 & 1.3584 \\
\hline D111 & 55.49 & 1728 & 0.052 & 15.005 & 8.11 & 4.7849 & 3.95 & 3.3251 & 0.0847 & 4.0347 & 3.25 & 0.095 & 0.127 & 0.497 \\
\hline D112 & 57.212 & 16.14 & 0.052 & 7.63 & 10.83 & 6.3897 & 4.49 & 4.4403 & 1.47 & 5.96 & 4.265 & 0.2116 & 0.38 & 1.788 \\
\hline D115 & 58.16 & 15.65 & 0.052 & 6.526 & 11.85 & 6.0435 & 4.67 & 5.8065 & 1.83 & 6.5 & 3.14 & 0.2108 & 0.3057 & 2.288 \\
\hline D116 & 59.04 & 16.11 & 0.052 & 8.83 & 8.68 & 5.03444 & 4.7649 & 3.64556 & 0.35 & 5.1149 & 3.45 & 0.168 & 0.62 & 2.646 \\
\hline D117 & 60.9375 & 15.518 & 0.052 & 7.11 & 9.247 & 4.80844 & 5.197 & 4.43856 & 1.02 & 6.217 & 3.79 & 0.18 & 0.34 & 1.8 \\
\hline D121 & 74.48 & 15.584 & 0.063 & 1.1139 & 2.11 & 0.844 & 4.544 & 1.266 & 5.569 & 10.113 & 0.43 & 0.1576 & 0.0945 & 0.5 \\
\hline D122 & 58.824 & 17.6 & 0.052 & 7.35 & 8.6 & 4.386 & 4.9 & 4.214 & 1.679 & 6.579 & 4.14 & 0.053 & 0.22 & 1.265 \\
\hline D124 & 58.23 & 16.29 & 0.052 & 67.1 & 10.63 & 5.5276 & 4.33 & 5.1024 & 1.479 & 5.809 & 3.746 & 0.188 & 0.3358 & 1.93 \\
\hline D125 & 48.85 & 13.45 & 0.052 & 8.33 & 12.43 & 7.5823 & 2.47 & 4.8477 & 0.659 & 3.129 & 14.4 & 0.216 & 0.278 & 1.89 \\
\hline D126 & 52.95 & 16.87 & 0.052 & 11.89 & 8.969 & 5.47109 & 3.05 & 3.49791 & 0.7999 & 3.8499 & 7.06 & 0.166 & 0.197 & 0.99 \\
\hline
\end{tabular}

Table 3. Correction for Loss On Ignition (L.O.I)

\begin{tabular}{|c|c|c|c|c|c|c|c|c|c|c|}
\hline sample & $\mathbf{S i O}_{2}$ & $\mathrm{Al}_{2} \mathbf{O}_{3}$ & $\mathbf{F e}_{2} \mathbf{O}_{3}$ & $\mathbf{C a O}$ & $\mathbf{N a}_{2} \mathbf{O}$ & $\mathbf{M g O}$ & $\mathbf{M n o}_{2}$ & $\mathbf{P}_{2} \mathbf{O}_{5}$ & $\mathbf{T i O}_{2}$ & $\mathbf{k}_{2} \mathbf{O}$ \\
\hline D42 & 54.27 & 15.37 & 9.67 & 8.04 & 3.48 & 4.95 & 0.141 & 0.161 & 1.179 & 1.67 \\
\hline D60 & 55.18 & 15.39 & 10.57 & 7.19 & 3.51 & 3.52 & 0.183 & 0.251 & 2.266 & 1.42 \\
\hline D44 & 53.28 & 15.39 & 10.37 & 8.68 & 2.89 & 6.34 & 0.153 & 0.156 & 1.222 & 0.71 \\
\hline D69 & 54.67 & 16.87 & 7.78 & 8.43 & 3.29 & 6.27 & 0.149 & 0.261 & 1.349 & 0.8 \\
\hline D31 & 69.66 & 15.34 & 3.28 & 2.45 & 4.71 & 0.28 & 0.062 & 0.039 & 1.3584 & 2.68 \\
\hline D45 & 59.42 & 16.27 & 8.25 & 5.48 & 4.59 & 1.26 & 0.165 & 0.373 & 0.497 & 1.98 \\
\hline D34 & 69.33 & 15.34 & 1.53 & 2.15 & 3.75 & 0.63 & 0.022 & 0.113 & 1.788 & 5.61 \\
\hline D41 & 65.57 & 18.32 & 1.67 & 2.01 & 5.84 & 0.42 & 0.021 & 0.067 & 2.288 & 4.86 \\
\hline D49 & 54.24 & 15.42 & 7.68 & 7.4 & 6.61 & 4.87 & 0.129 & 0.121 & 2.646 & 2.01 \\
\hline
\end{tabular}


Table 4. Normative mineralization calculation of studied samples

\begin{tabular}{|l|l|l|l|l|l|l|l|l|l|l|l|l|l|l|l|}
\hline sample & Ap & Tn & Hm & Cs & Ol & Hy & Di & Kp & Ne & Lc & An & Ab & Or & C & Q \\
\hline D102 & 0.419 & 2.894 & 3.377 & 0 & 0 & 6.072 & 28.241 & 0 & 0 & 0 & 28.691 & 21.324 & 3.546 & 0 & 2.19 \\
\hline D103 & 0.348 & 5.563 & 4.108 & 0 & 0 & 6.173 & 7.907 & 0 & 0 & 0 & 35.412 & 35.116 & 1.992 & 0 \\
\hline D104 & 0.55 & 3 & 2.902 & 0 & 0 & 1.614 & 13.82 & 0 & 0 & 0 & 11.945 & 46.666 & 15.885 & 0 \\
\hline D105 & 0.68 & 3.312 & 3.194 & 0 & 0 & 2.101 & 9.545 & 0 & 0 & 0 & 11.109 & 45.228 & 16.955 & 0 & \\
\hline D109 & 0.317 & 3.335 & 3.909 & 0 & 0 & 5.057 & 36.982 & 0 & 0 & 0 & 24.524 & 18.074 & 1.466 & 0 \\
\hline D111 & 0.301 & 0 & 3.325 & 0 & 5.673 & 0 & 0 & 0 & 2.398 & 0 & 73.613 & 28.997 & 0.051 & 1694.432 & 0 \\
\hline D112 & 0.9 & 4.389 & 4.44 & 0 & 0 & 7.159 & 7.472 & 0 & 0 & 0 & 19.543 & 37.993 & 8.687 & 0 & 7.251 \\
\hline D115 & 0.724 & 5.617 & 5.806 & 0 & 0 & 5.629 & 4.728 & 0 & 0 & 0 & 16.335 & 39.516 & 10.815 & 0 \\
\hline D116 & 1.469 & 6.496 & 3.646 & 0 & 0 & 5.344 & 7.009 & 0 & 0 & 0 & 21.535 & 40.319 & 2.068 & 0 & 9.223 \\
\hline D117 & 0.805 & 4.419 & 4.438 & 0 & 0 & 5.55 & 8.392 & 0 & 0 & 0 & 16.001 & 43.976 & 6.028 & 0 & 11.604 \\
\hline D121 & 0.224 & 0 & 1.266 & 0 & 0 & 1.071 & 0 & 0 & 0 & 0 & 4.909 & 38.45 & 32.911 & 0.282 & 23.56 \\
\hline D122 & 0.521 & 3.105 & 4.214 & 0 & 0 & 6.865 & 7.435 & 0 & 0 & 0 & 21.069 & 41.462 & 9.922 & 0 & 0 \\
\hline D124 & 0.795 & 0 & 5.102 & 93.897 & 6.539 & 0 & 0 & & 19.849 & 12.652 & 20.644 & 0 & 0 & 0 & 0 \\
\hline D125 & 0.658 & 4.64 & 4.848 & 0 & 7.378 & 21.998 & 7.208 & 0 & 0 & 0 & 23.666 & 20.9 & 3.894 & 0 & 0 \\
\hline D126 & 0.467 & 2.43 & 3.498 & 0 & 0 & 8.826 & 18.895 & 0 & 0 & 0 & 29.978 & 25.808 & 4.727 & 0 & 2.687 \\
\hline
\end{tabular}

Table 5. Normative mineralization calculation for samples with XRF analysis

\begin{tabular}{|l|l|l|l|l|l|l|l|l|l|l|l|l|l|}
\hline sample & Q & Or & Ab & An & Ne & Di & Hy & Ol & Hm & Tn & Pf & Ru & Ap \\
\hline D42 & 7.251 & 9.869 & 29.447 & 21.385 & 0 & 10.387 & 7.514 & 0 & 9.67 & 2.894 & 0 & 0 & 0.381 \\
\hline D60 & 11.971 & 8.392 & 29.701 & 22.043 & 0 & 3.187 & 7.29 & 0 & 10570 & 5.563 & 0 & 0 \\
\hline D44 & 9.406 & 4.196 & 24.454 & 26.923 & 0 & 8.456 & 11.872 & 0 & 10.37 & 3 & 0 & 0 \\
\hline D69 & 8.219 & 4.728 & 27.839 & 28.9 & 0 & 5.074 & 13.265 & 0 & 7.78 & 3.312 & 0 & 0 & 0.37 \\
\hline D31 & 26.449 & 15.838 & 39.855 & 11.9 & 0 & 0 & 0.697 & 0 & 3.28 & 0 & 0 & 1.359 & 0.092 \\
\hline D45 & 14.045 & 11.701 & 38.839 & 17.943 & 0 & 3.951 & 1.307 & 0 & 8.25 & 1.22 & 0 & 0 & 0.883 \\
\hline D34 & 21.138 & 33.153 & 31.731 & 8.454 & 0 & 0 & 1.569 & 0 & 1.53 & 1.039 & 0 & 1.365 & 0.268 \\
\hline D41 & 8.281 & 28.721 & 49.416 & 9.419 & 0 & 0 & 1.046 & 0 & 1.67 & 0.081 & 0 & 2.256 & 0.159 \\
\hline D49 & 0 & 11.878 & 45.283 & 6.467 & 5.769 & 15.753 & 0 & 3.383 & 7.68 & 0 & 4.505 & 0 & 0.287 \\
\hline
\end{tabular}




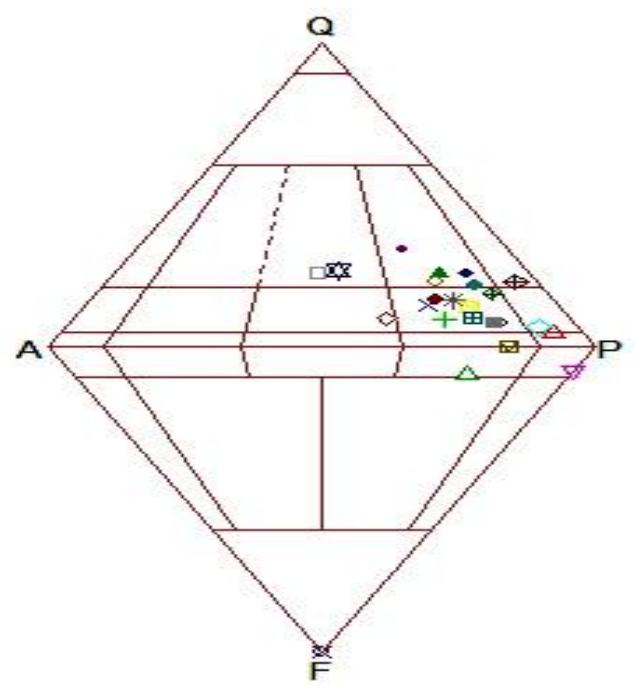

Figure 12. QAPF diagram (Streckeisen 1974) for silica-saturated plutonic igneous rocks

According to the results of the chemical analysis, the under study rocks include granite, granodiorite, quartz monzonite, quartz monzo gabbro diorite, and foid gabbro diorite.

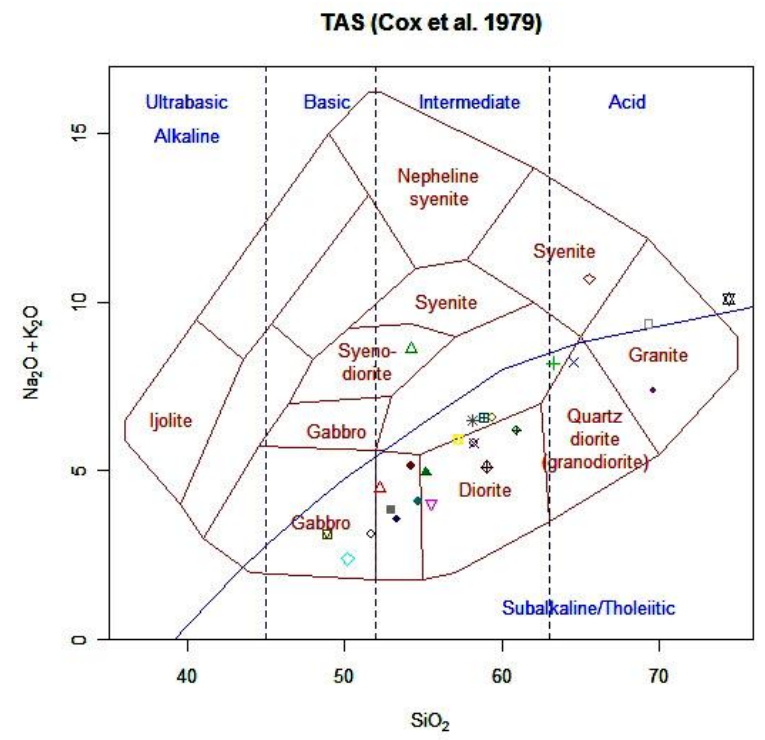

Figure 13. $\mathrm{Si}_{2} \mathrm{O}-\mathrm{Na}_{2} \mathrm{O}+\mathrm{K}_{2} \mathrm{O}$ plot TAS (Cox et al 1979)

According to TAS (Cox et al, 1979) for plutonic rocks, three samples are in alkaline range and the rest are in sub alkaline and tholeiitic range. 


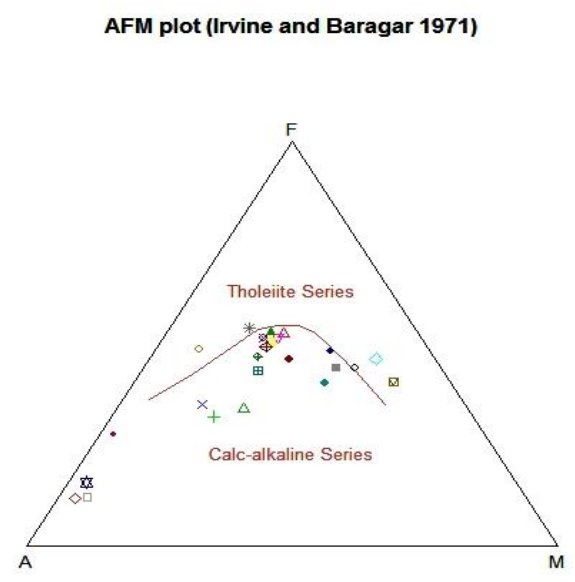

Figure 14. AFM plot (Irvine and Baragar 1971)

According to the AFM diagram, most of the samples are in the calk- alkaline series and a few are in the tholeiitic series.

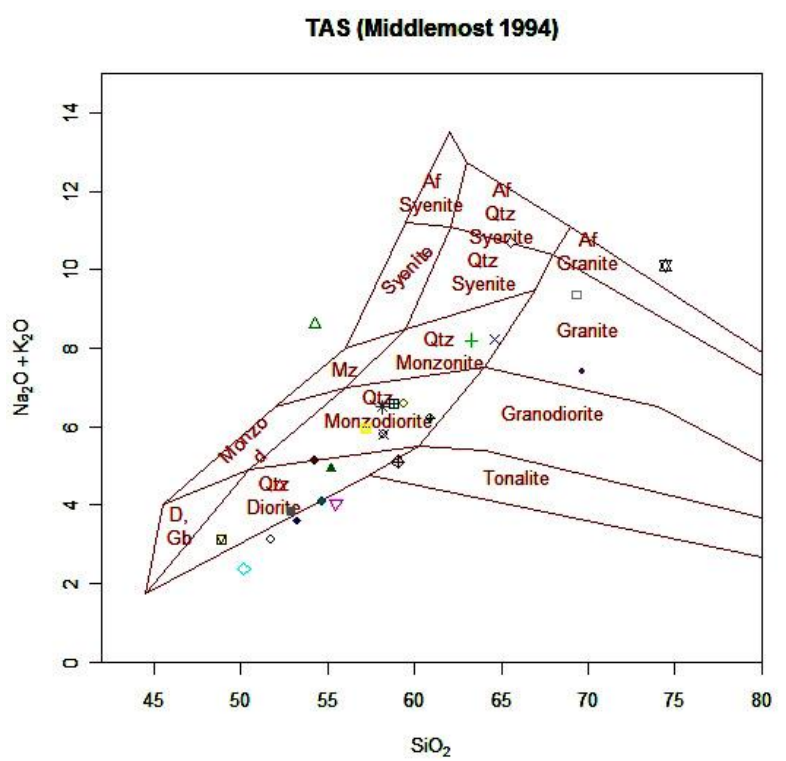

Figure 15. $\mathrm{SiO}_{2}-\mathrm{Na}_{2} \mathrm{O}+\mathrm{K}_{2} \mathrm{O}$ plot TAS (Middlemost 1994)

As shown by TAS alkaline silica graph (Middlemost, 1994) for plutonic rocks, 5 samples are out of the chart range, 2 samples are in the granite area, 2 samples in the quartz monzonite area, 1 sample in the tonalite area, 6 samples in the quartz monzonite area and the rest of the samples are in the quartz diorite zone. 


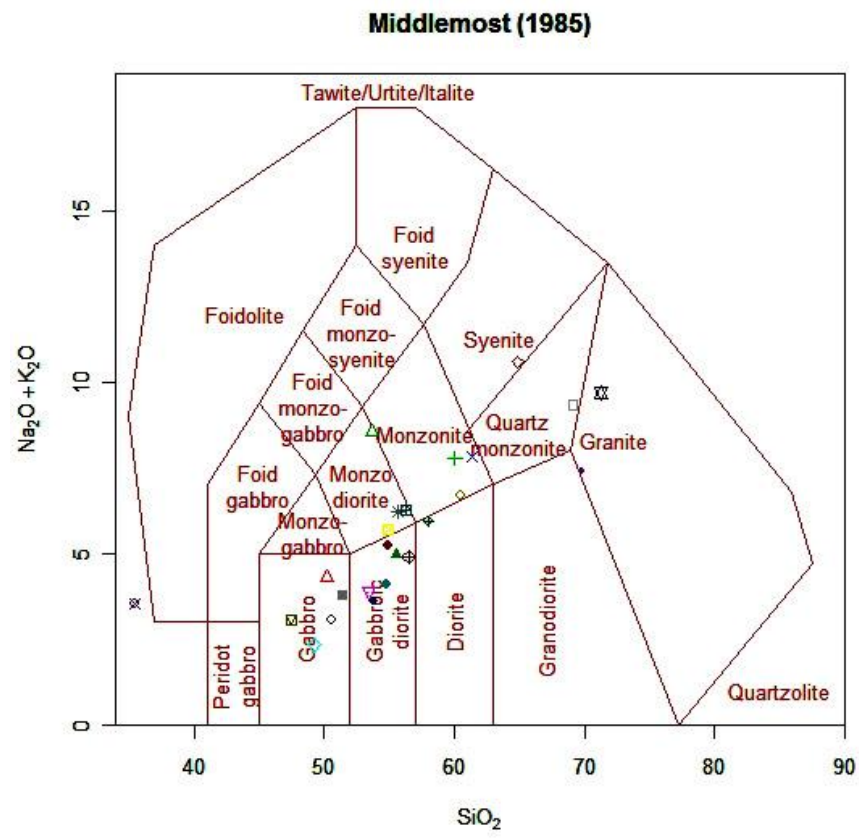

Figure 16. $\mathrm{SiO}_{2}-\mathrm{Na}_{2} \mathrm{O}+\mathrm{K}_{2} \mathrm{O}$ plot (Middlemost 1985)

From the matching of plutonic sample data on TAS alkaline silica aggregate (Middlemost, 1985) for plutonic rocks, the studied samples are stretched from gabbro to granite range.

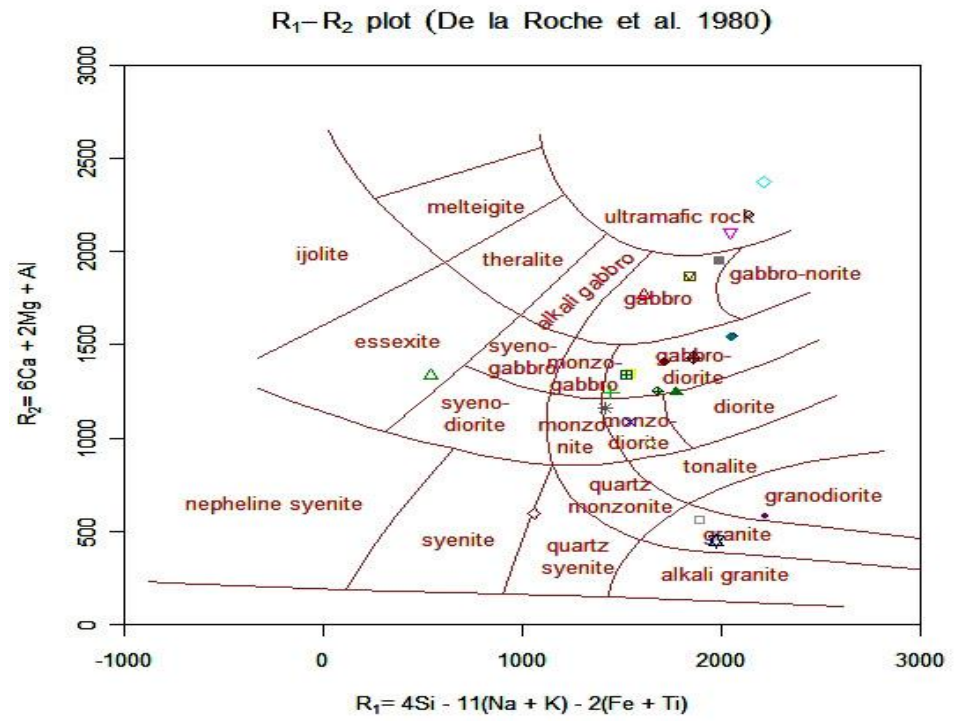

Figure 17. R1-R2 plot (De la Roche et al. 1980)

As shown in the above graph, 2 samples are in granite zone, 1 in granodiorite zone, 1 in quartz syenite, 1 in monzo-diorite, 1 in essexite, 2 in ultramafic rocks, 3 in the gabbro zone and the rest of the samples are located in the gabbro diorite zone. 


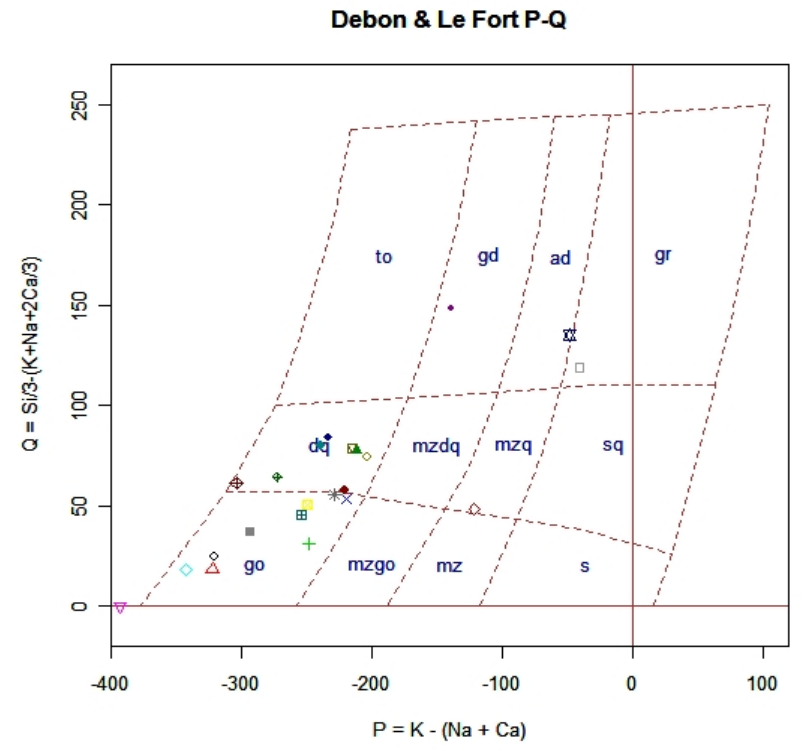

Figure 18. P-Q plot (Debon \& Le Fort 1983)

In the figure (P, Q1983 Debon and Lee Fort), 1 sample is in the granite area, 1 sample in the granite and adamlite area, 1 sample in the quartz monzonite area, 6 samples in the quartz diorite range and the rest of the samples are in the gabbro range.

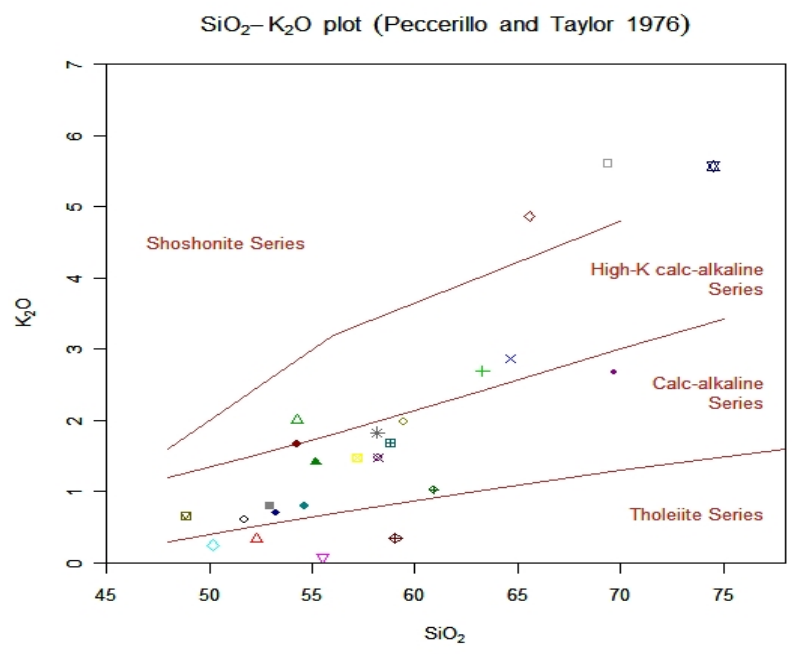

Figure 19. $\mathrm{SiO}_{2}-\mathrm{K}_{2} \mathrm{O}$ plot (Peccerillo \& Taylor 1976)

According to the Peccerillo \& Taylor 1976 diagram, 3 samples are in the shoshonite series, 4 samples are in the toilet series, 3 samples are in the high potassium calk-alkaline region, and the rest of the studied samples are in the calk-alkaline series. Potassium-rich rocks and the shoshonite series are present in places where the Benioff Seismic Zone is deep or seen in areas where locally extensional tectonics is prevalent (Middlemost, 1987). These rocks also appear only in continental regions and have not been found in oceanic crusts. 


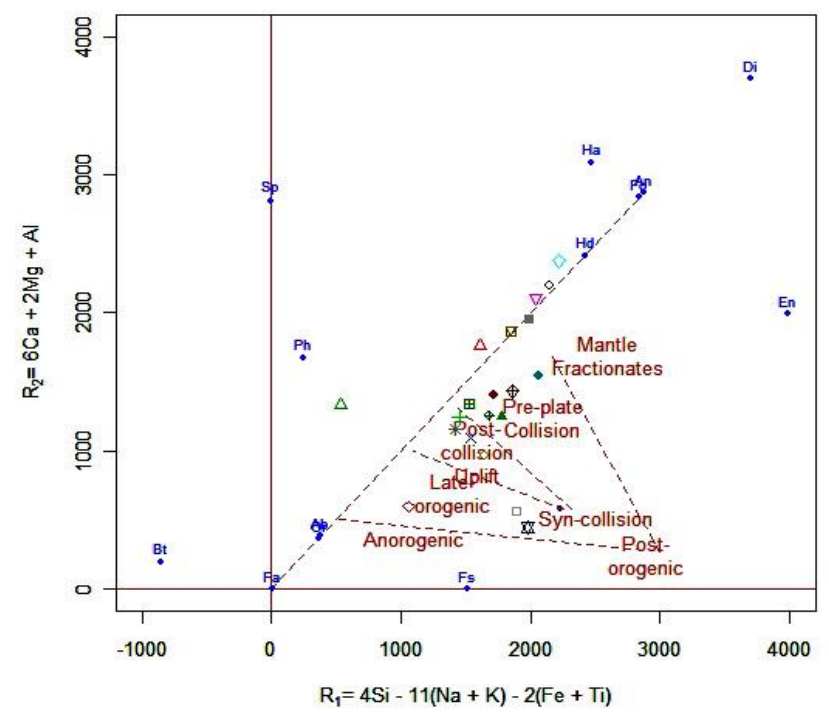

Figure 20. $\mathrm{R}_{1} \mathrm{R}_{2}$ Batchelor \& Bowden plot.

According to the chart, most of the samples are in pre-plate and post-collision zones, some of the samples are in late orogenic zone, some are in syn-collision zone and the rest of the samples are located outside this chart but close to mantle fractionates zone.
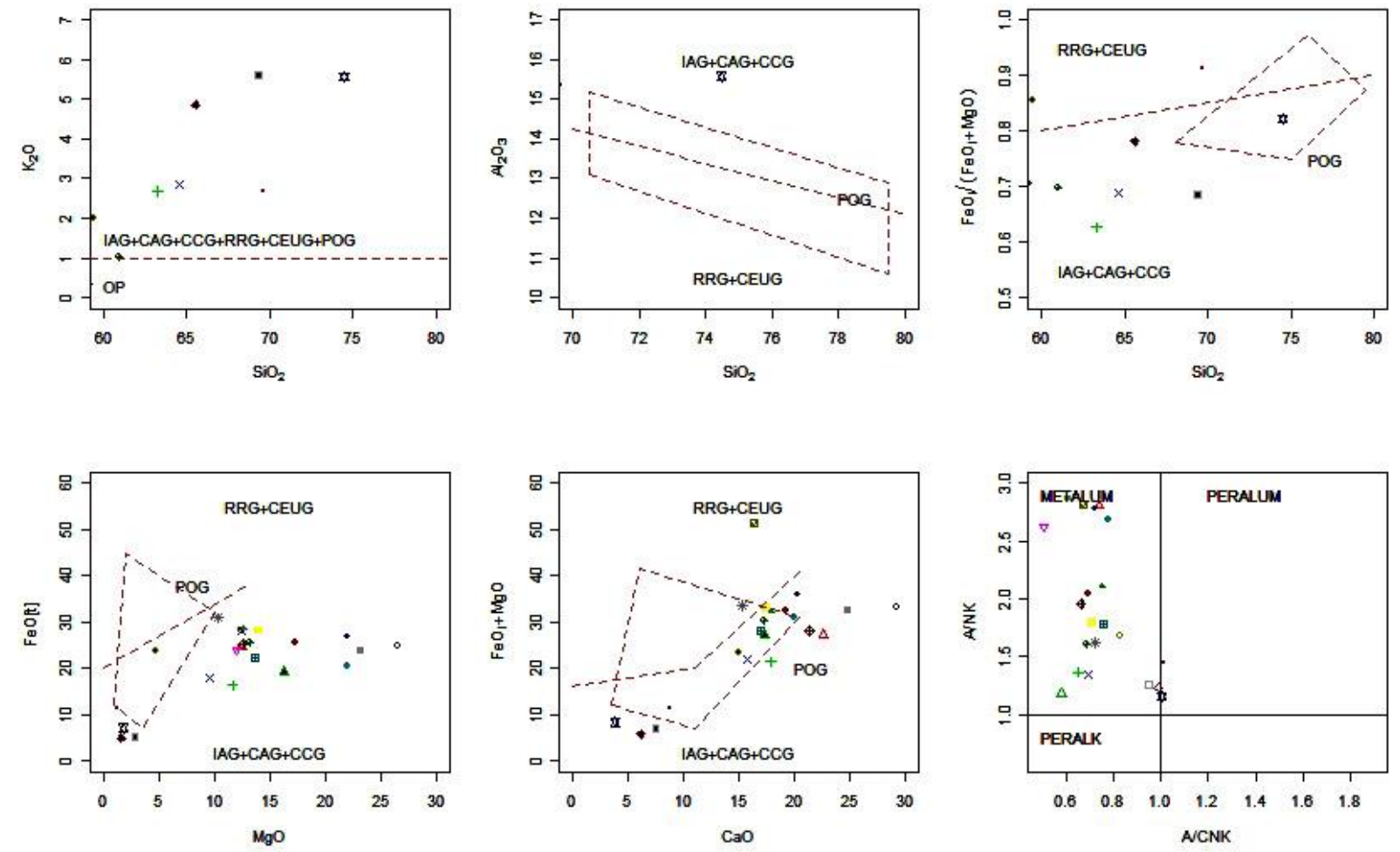

Figure 21. Maniar and Piccoli (1989) plots. 
In these charts, most of the samples are meta alumina and plotted in CCG, CAG, and IAG zones.

\author{
CCG: Continental Crust Granites IAG: Island Arc Granites CAG: Continental Arc \\ Granites
}

\title{
7. CONCLUSION
}

According to field of study conclusions, the following results were obtained:

Plutonic masses were studied in the north of Sonqor in Kermanshah province and between Varmaqan in the east of the study area and Sardare Ghobadi to the west of the study area. The study area contains alkaline granite, granite, granodiorite, tonalite, quartz alkaline syenite, quartz monzonite, quartz monzodiorite, quartz diorite, alkaline syenite, monzonite, diorite, gabbro diorite, gabbro, and olivine gabbro.

These stones are light to medium in color (leucocrat to mesocrat) in hand specimen with little alteration. The principal constituents of these rocks are quartz, orthos, and plagioclase, and biotite, zircon, apatite, and opaq minerals are the minor minerals. Severe chloritization and apacitization in biotite, sericitization and kaolinitization in plagioclase and kaolinitization in orthoses in granites and granitoids have occurred in great volumes.

Based on the results of delineated graphs such as Middlemost (1985) based on $\left(\mathrm{Na}_{2} \mathrm{O}+\mathrm{K}_{2} \mathrm{O}\right)$ / $\left(\mathrm{SiO}_{2}\right)$, Cox et al. (1979) based on $\left(\mathrm{Na}_{2} \mathrm{O}+\mathrm{K}_{2} \mathrm{O}\right) /\left(\mathrm{SiO}_{2}\right)$ as well as Middlemost (1994) based on $\left(\mathrm{Na}_{2} \mathrm{O}+\mathrm{K}_{2} \mathrm{O}\right) /\left(\mathrm{SiO}_{2}\right)$ and Debon \& Le Fort (1983) based on the Q / P plot and normative calculations of the samples, it is concluded that the rocks classified by the CIPW method include: gabbrodiorite, monzodiorite, granite, granodiorite and syenites and all show genetic dependence.

It seems that the magmas of all the plutonic rocks in the region appear to have a common origin caused by magmatic differentiation and fractional crystallization and differ from intermediate to acidic terms. All granites in this study are I type.

Two-dimensional diagrams of Irvine and Baragar were used to determine the magmatic series of plutonic rocks. The following results were obtained: Most of the samples were sub-alkaline with a calk-alkaline nature.

Peccerillo and Taylor's, 1976 diagram, based on the $\mathrm{K}_{2} \mathrm{O}$ to $\mathrm{SiO}_{2}$ ratio, plots these rocks in three sections: calk-alkaline, potassium-high calk-alkaline and shoshonite. Conclusion of Maniar and Piccoli ,1989 diagrams is that the samples are of meta-alumina type and they have high percentages of aluminum.

Harker's diagrams ,1909 are plotted on the basis of major oxide changes of plutonic rocks of the region in ratio with silica, and the following results were obtained:

The abundance of $\mathrm{Al}_{2} \mathrm{O}_{3}$ in the less acidic and acidic terms is approximately equal but increases in the intermediate acidic terms, increased plagioclase crystallization is the main reason. The slope of the $\mathrm{Fe}_{2} \mathrm{O}_{3}$ diagram decreases from lower acidic to acidic terms which is mainly due to the presence of this element in amphibole, augite and magnetite minerals. The presence of $\mathrm{Ca}$ in the structure of augite and calcic plagioclase has caused $\mathrm{CaO}$ to be much higher in the less acidic term than the acidic term. The increase of $\mathrm{Na}_{2} \mathrm{O}$ from basic terms to acidic terms indicates that the early magma was initially poor in $\mathrm{Na}$, but after crystallization of calcic plagioclases and augite and the depletion of $\mathrm{Fe}, \mathrm{Ca}$ and $\mathrm{Mg}$, $\mathrm{Na}$ levels increased in left over magma. The abundance of potassium in the rocks of the area indicates irregularities, potassium is 
a strong hydromagmatophilic element and due to its high ionic radius, in the late stages of magma evolution it is consumed in acidic rocks and enters the feldspar mineral lattice, thereby its amount from less acidic rocks to acidic rocks is associated with increased irregularity. The curve slope of the $\mathrm{MgO}$ diagram relative to $\mathrm{SiO}_{2}$, descends from less acidic to acidic terms because of magnesium consumption in amphibole and augite minerals formation. The high abundance of $\mathrm{TiO}_{2}$ in the plutonic rocks indicates a downward trend towards acidic terms.

Examination of major elements oxidation diagrams in relative to the differentiation index (D.I) showed that partial crystallization of amphibole, augite, and calcic plagioclase caused magma to be depleted of iron, magnesium and calcium, and with increasing magmatic crystallization, the amount of elements such as sodium increased.

Based on tectono magmatic positioning diagrams of Maniar \& Piccoli 1989, our samples are of meta alumina type and they are located in the ranges of CCG, IAG andCAG. The basic magmas in the study area are of mantle origin because of high percentages of Fe and $\mathrm{Mg}$ and a low percentage of $\mathrm{SiO}_{2}$, which as acidic magmas originate from these basic magma fractionation and crustal contamination.

\section{REFERENCES}

Ashrafi, N., Hasebe, N., Jahangiri, A (2018) Cooling history and exhumation of the Nepheline Syenites, NW Iran: Constraints from Apatite fission track, Iranian Journal of Earth $\quad$ Sciences, 10(2) pp 109-120.

Baratian, M., Arian, M.A., \& Yazdi, A (2020) Petrology and Petrogenesis of Siah Kooh volcanic rocks in the eastern Alborz, GeoSaberes, v. 11, p. 349-363. DOI: https://doi.org/10.26895/geosaberes.v11i0.980.

Berberian, M (1973). Two important deformational and metamorphic phases in the belt north east of Zagros thrust line (Iran). A brief structural review of Sanandaj-Sirjan belt.Geol.Surv.Iran.,Rep.no.27,35p.

Chappel, B.W. and White, A.J.R (1974) Two contrasting granite types. Pacific geology,

8. pp.173-174.

Cox, K.G.; Bell, J.D.; Pankhurst, R.J (1979) The interpretation of igneous rocks. 450 p.

De la Roche, H., Leterrier, J., Grandclaude, P., and Marchal, M (1980) A classification of volcanic and plutonic rocks using $R_{1} R_{2}$ - diagram and major element analyses- Its relationships with current nomenclature: Chemical Geology, v.29, p. 183-210.

Debon, F., and LeFort, P (1983) A Chemical-Mineralogical classification of common plutonicrocks and associations. Transactions of the royal study of Edinburgh: Earth sciences,73, 135-149.

Harker, A (1909) The Natural history of igneous rocks. Pp. 384.

Irvine, T.N., and Baragar, W.R.A (1971) A guide to the chemical classification of the commonvolcanic rocks. Canadian journal of earth science, $8,523-548$.

Jamshidibadr, M., Tarabi, S., Gholizadeh, K (2020) Study of micro-textures and _ chemistry of feldspar minerals of East Sarbisheh volcanic complex (Eastern Iran), for evidence of magma chamber process,

Iranian Journal of Earth Sciences, 12(1) pp 10-31.

Mac Kenzie,W.S., and Donaldson,C.H, and Guilford,C (1982). Atlas of igneous rocks and their structures.

Mac Kenzie,W.S., and Guilford,C (1982). Atlas of rock forming minerals in thin section. 
Maniar, P.D., and Piccoli, P.M (1989) Tectonic discrimination of granitoids. Geological society of America bulletin, $101,635-643$.

Middlemost, E.A.K (1985) Magmas and magmatic rocks. An introduction to igneous petrology. Longman group Ltd., London, New York, 266 p.

Middlemost, E.A.K (1985) Magmas and magmatic rocks. An Introduction to igneous petrology. Longman group limited.

Middlemost, E.A.K (1994). Naming materials in the magma/igneous rock system. Earth-science reviews, 37, 215244.

Mobashergermi, M., Zarei Sahamieh, R., Aghazadeh, M., Ahmadikhalaj, A., Ahmadzadeh, G

(2018) Mineral chemistry and thermobarometry of Eocene alkaline volcanic rocks in SW Germi, NW Iran, Iranian Journal of Earth Sciences, 10(1) pp 39-51.

Nazemi, E., Arian, M.A., Jafarian, A., Pourkermani, M., Yazdi, A (2019) Studying The Genesis Of Igneous Rocks In Zarin-Kamar Region (Shahrood, Northeastern Iran) By Rare Earth Elements, Revista Gênero e Direito, 8(4), 446-466. DOI: $\quad$ https://doi.org/10.22478/ufpb.2179-7137.2019v8n4.48442

Peccerillo, A., and Taylor, S.R (1976) Geochemistry of Eocene calk-alkaline volcanic rocks from the Kastamonu area, northern Turkey. 58, 63-81.

Stoklin, J (1968) Strutural history and tectonics of Iran; a review. American association of Petroleum Geologists Bulletin, 52. pp.1229-1258.

Streckeisen, A (1974) Classification and nomenclature of plutonic rocks: Recommendations of the IUGS subcommision on the systematics of igneous rocks.63, 773-786.

Tarabi, S., Emami, M.H., Modabberi, S., Sheikh Zakariaee, S.J (2019) Eocene- Oligocene volcanic units of momen abad, east of Iran: petrogenesis and magmatic evolution, Iranian Journal of Earth Sciences, 11(2) pp 126-140.

Yazdi, A., Ashja Ardalan, A., Emami, M.H., Dabiri, R., Foudazi, M (2019) Magmatic interactions as recorded in plagioclase phenocrysts of quaternary volcanics in SE Bam (SE Iran), Iranian Journal of Earth Sciences, 11(3) pp 215-225. 